Columbia Law School

Scholarship Archive

1980

\title{
Judicial Review and the National Political Process: A Functional Reconsideration of the Role of the Supreme Court
}

Henry Paul Monaghan

Columbia Law School, monaghan@law.columbia.edu

Follow this and additional works at: https://scholarship.law.columbia.edu/faculty_scholarship

Part of the Supreme Court of the United States Commons

\section{Recommended Citation}

Henry P. Monaghan, Judicial Review and the National Political Process: A Functional Reconsideration of the Role of the Supreme Court, HARV. L. ReV. (1980).

Available at: https://scholarship.law.columbia.edu/faculty_scholarship/788

This Book Review is brought to you for free and open access by the Faculty Publications at Scholarship Archive. It has been accepted for inclusion in Faculty Scholarship by an authorized administrator of Scholarship Archive. For more information, please contact scholarshiparchive@law.columbia.edu. 


\section{BOOK REVIEWS}

Judicial Review and the National Political Process: A Functional Reconsideration of the Role of the SuPREME Court. By Jesse H. Choper. ${ }^{1}$ Chicago: The University of Chicago Press. I980. Pp. xviii, 494. \$28.50.

Reviewed by Henry P. Monaghan ${ }^{2}$

I.

Imagine a cold morning early in February. Slowly sipping coffee in an effort to awaken fully, you are reading through the Supreme Court advance sheets. You come across the following brief opinion:

Per CuRIAM. Fisher v. Rye Co., No. 8I-I, and First Savings Bank v. Smith, No. 8I-2. These petitions for certiorari have been consolidated for disposition in a single opinion. No. 8I-I challenges an Executive Order that, in an effort to combat gender-based discrimination, requires government contractors to adopt affirmative action programs. No argument is made that the Executive Order is authorized by statute. Concluding that the President's order could not be embraced by any inherent residuum of "emergency" presidential authority, cf. Youngstown Sheet \& Tube Co. v. Sawyer, 343 U. S. 579 (1952), the courts below held that the Executive Order was an impermissible assertion of legislative power. In No. 8I-2, petitioner, a state-chartered institution, asserts the invalidity of a federal statute prohibiting discrimination on the basis of marital status in the issuance of mortgages and other loans. Relying upon our decision in Heart of Atlanta Motel, Inc. v. United States, 379 U. S. 24I (1964), and, more fundamentally, upon the principles set forth in M'Culloch v. Maryland, I7 U. S. (4 Wheat.) 3 I6 (I8I9), the courts below sustained the statute as a rational exercise of the power to regulate interstate commerce.

The petitions are granted, the judgments vacated, and the cases remanded with directions to dismiss the complaints for want of jurisdiction. We hold that these separation of powers and federalism claims present non-justiciable political questions.

The central function of the courts established by Article III, and particularly of this Court, is to vindicate individual liberties. History teaches that these liberties are not ade-

\footnotetext{
1 Professor of Law, University of California at Berkeley.

2 Professor of Law, Boston University; Harry Kalven, Jr. Visiting Professor, University of Chicago.
} 
quately secured by our majoritarian political process. But these liberties are not sharply implicated by either federalism or separation of powers challenges, since it is conceded that some governmental unit could impose the challenged restriction. Essentially, therefore, the challenges in both cases are based on conflicting assertions of political power between governmental actors. The constitutional structure thus ordains that such claims be adjusted in the political process, which, we are satisfied, adequately protects both the interests of the States and of Congress. Moreover, history teaches that judicial intervention in these areas necessarily weakens this Court's ability to discharge its principal role of vindicating individual liberties. See generally, J. Choper, Judicial Review and the National Political Process ( 1980 ).

M'Culloch v. Maryland, supra, and its progeny are no longer authoritative insofar as they assume the justiciability of federalism issues. Our prior cases dealing with presidential claims of constitutional authority are similarly disapproved to the extent that they depend on the justiciability of such claims. Of course, the courts remain free to adjudicate cases in which the sole issue is one of statutory construction: where the President's sole reliance is upon statutory authority or where the President is alleged to have acted in a manner prohibited by statute and he concedes that such a prohibition would be valid.

By the time you had read this imaginary opinion, your need for coffee would, in all probability, have vanished. The opinion's startling and intriguing thesis is the core of Professor Choper's complex and fascinating, but ultimately frustrating, Judicial Review and the National Political Process.

Professor Choper opens with the enduring problem of constitutional theory: can judicial review be reconciled with the fundamental presuppositions of democracy, with its emphasis on the majoritarian political process? In the opening chapter, he argues that neither in theory nor in practice is the Supreme Court as democratic - as politically accountable - as the political branches of the national government. Nonetheless he is able to find an appropriate role for judicial review in, to coin a phrase, "Our Democracy." 3 To determine the nature of this role, Choper takes an avowedly functional approach. ${ }^{4}$ His central thesis is that judicial review is warranted only

3 "American working democracy is the grand product of the efforts and interactions of all legal and political structures in the nation, influenced at different points with varying intensities by the multitude of economic and social organizations that function outside the formal system of government" (pp. IO-II).

${ }^{4}$ Choper's approach is grounded in "the practical operation of the American political process from the perspective of democratic theory" (p. II). 
when the majoritarian political process cannot be assumed to vindicate the constitutional interests at stake. In chapter 2 , Choper argues that this perspective completely justifies judicial review in the area of civil liberties.

Chapter 3 elaborates another important thesis: judicial review is a politically fragile institution, and it is, therefore, a serious mistake to assume that the Court possesses inexhaustible institutional capital. Chapters 4 and 5 build on these themes. There Choper asserts that the Court unjustifiably expends its capital in reviewing federalism and separation of powers claims, neither of which clearly threaten individual liberty. Instead, he proposes, the Court should recognize that the constitutional system provides adequate political mechanisms for maintaining a balance among the various political organs of government and, accordingly, should deem federalism and separation of powers claims inappropriate for judicial resolution. He argues in the last chapter that a more appropriate role for the Court is preventing the political branches from improperly expanding or restricting judicial review.

\section{II.}

The most provocative aspects of Choper's book appear in these final three chapters. Here, he focuses on "constitutive" matters, concerning the Constitution as a system for allocating power, both between the states and the national government and within the national government itself. ${ }^{5}$ Admitting that constitutional questions requiring "resolution" may arise in this context, Choper denies that they require resolution by judges. In his thorough discussion of the "political" mechanisms available for deciding these issues, Choper provides a valuable corrective for the myopia of those who see judicial decisions as the only possible source of our constitutional "law." But Choper goes much further: he denies any judicial role, even at the margins, in either the federalism or the separation of powers area. ${ }^{6}$ In his view, these struggles should be treated as nonjusticiable political questions, beyond article III's grant of "judicial power."

Choper adduces two central justifications for this sweeping position. First, he makes the structural argument that the

\footnotetext{
5 See B. Eckhardt \& C. Black, The Tides of Power I, 9 (1976).

${ }^{6}$ Choper stresses, however, that the courts must address any independent individual liberties claims involved in these cases. See pp. 197-98, 326-30.

7 I do not pause to compare Choper's use of the "political question" terminology with its current usage, assuming that the existing doctrine possesses coherence. See Henkin, Is There a "Political Question" Doctrine?, 85 YALE L.J. 597, 622-23 (1976).
} 
constitutional interests at stake are adequately secured by the political system. Second, Choper focuses on prudential concerns, contending that judicial intervention in either area imposes costs on the judicial branch, diminishing the Court's capacity to protect individual rights. Whether these justifications are sufficient to warrant so major a reorientation of our understanding of the appropriate role of the Supreme Court presents questions to which I now turn.

\section{A. Federalism: The Politics of Representation}

Emphasizing that "the national political process . . . is intrinsically well-adapted to retarding or restraining new intrusions by the center on the domain of the states," Herbert Wechsler long ago argued in a classic essay that the Court was on its "weakest ground" in opposing Congress on behalf of the states. $^{8}$ Professor Choper rigorously and carefully elaborates this insight, with impressive attention to the empirical basis for the claim that state interests are adequately represented in the national political process. ${ }^{9}$

Few today would deny that the structure of "Our Federalism" 10 is "political" in the sense that the actual allocation of power between the national government and the states is determined by Congress. "The radical transformation that has occurred in the structure of 'Our Federalism' in the nearly two centuries of our existence has emptied the concept of nearly all legal content and replaced it with a frank recognition of the legal hegemony of the national government." 11 The courts are simply incapable of setting principled limits on what Congress may do pursuant to its commerce, spending, and taxing powers, or pursuant to the grants of power made by the Civil War amendments. ${ }^{12}$ To be sure, National League of Cities $v$.

${ }^{8}$ Wechsler, The Political Safeguards of Federalism: The Role of the States in the Composition and Selection of the National Government, 54 CoLUM. L. REv. 543, 558-59 (I954), reprinted in $\mathrm{H}$. WeChSLER, PRINCIPLes, Politics, aNd FundameNTAL LAW 49, 78, 80-8I (I96I).

${ }^{9}$ One commentator, however, has recently raised an explicit challenge to the adequacy of the political safeguards of federalism. Kaden, Politics, Money, and State Sovereignty: The Judicial Role, 79 CoLUM. L. Rev. 847, 857-68 (I979).

${ }^{10}$ See Younger v. Harris, 40I U.S. 37, 44 (197I).

11 Monaghan, The Burger Court and "Our Federalism," Law \& ConTEMP. ProB., Summer 1980 , at 39,39 .

$12 \mathrm{See}$ id. at 40-43. The Court could, perhaps, maintain the position of the Civil Rights Cases, rog U.S. 3 (I883), that private conduct cannot be reached by Congress under the r4th amendment. But see Cox, The Role of Congress in Constitutional Determinations, 40 U. CIN. L. REV. 199, 239-47 (I97I); Monaghan, The Supreme Court, 1974 Term - Foreword: Constitutional Common Law, 89 HARV. L. REv. I (I975). 
Usery ${ }^{13}$ stands as one attempt to draw some limits. But Usery increasingly appears to be a constitutional sport rather than the wellspring of significant additional restraints on the national government. ${ }^{14}$ The real question is whether the difficulty of framing meaningful constitutional limits on national power should lead us to rethink the whole course of constitutional history and treat these federalism issues as political in the sense of being "nonjusticiable." 15 Stare decisis has its claims for me; ${ }^{16}$ Choper's case, to be persuasive, must demonstrate that long-established principles work manifest inconvenience or harm. ${ }^{17}$

Choper of course does not rest his case on the correctness of a single decision like Usery. His general argument centers on the need to protect the "fragile institution" of judicial review in vindicating civil liberties. Choper points to the considerable past hostility to the Court's federalism decisions, shrewdly noting that the hostility was often a reaction to decisions upholding federal legislation (pp. I29, 230-33). But does this history prove that such reactions are likely to recur? Choper cites no modern federalism decisions generating comparable responses. In one case last Term, for example, the Court upheld federal legislation restricting the state electoral process. ${ }^{18}$ I noticed no public outcry and would have been

${ }^{13} 426$ U.S. 833 (1976).

${ }^{14}$ See Monaghan, supra note II, at 42 . But see United Transp. Union v. Long Island R.R., 49 U.S.L.W. 2212 (2d Cir. Sept. 15, r980) (court relied on Usery in holding that right-to-strike provision of Federal Railway Labor Act, 45 U.S.C. $\$ \S$ 151-188 (1976), interfered with New York's "integral governmental functions" in operating public service commuter railroad and therefore did not preempt state law prohibiting strikes by public employees).

${ }^{15}$ Choper observes in this connection that judicial review requires a determination of who really "speaks" for the state (pp. $18 \mathrm{I}-84$ ) - and that it is anomalous that private parties have standing to raise federalism claims even when the state does not object to the federal law (pp. 203-05). Cf. Monaghan, Constitutional Adjudication: The Who and When, 82 YALE L.J. I363, 1367 (1973) (until this century, federalism issues could be litigated in private suits without appropriate federal or state officials being notified).

${ }^{16}$ See Monaghan, Taking Supreme Court Opinions Seriously, 39 MD. L. REv. I, I-I2 (I979).

${ }^{17}$ Even if Choper did convincingly establish manifest harm, I wonder if he has not carried his nonjusticiability thesis further than its underlying rationale will support. Perhaps the dynamics of the national political process adequately protect the states, even when federal legislation has a regional bite. But the political safeguards are not as effective when a single state claims ownership of specific property or a specific resource as against the national government. See pp. 200-or (discussing United States v. California, 332 U.S. Ig (1947)). And there is no reason to assume that the protective dynamic operates at all when the issue is whether new states unrepresented in Congress - must be admitted on an "equal footing" with existing ones. See p. 194 (rejecting the "equal footing" holding of Coyle v. Smith, 221 U.S. 559 (IgIr)). See also B. EckHARDT \& C. BLACK, supra note 5, at 8-9.

${ }^{18}$ City of Rome v. United States, I00 S. Ct. I548 (1980). 
surprised had one been forthcoming. Constitutional battles over the allocation of power between nation and states occupied center stage for close to two centuries in our constitutional history, but those battles are now over, and their results generally accepted. ${ }^{19}$ Thus, it does not help Choper to argue that any grievances felt against the Court are intense and cumulative in nature (pp. I33-36, I56-6I, 256-57), for no solid basis exists for believing that the Court's modern federalism decisions contribute anything significant to the grievances, and changing course now will not eliminate past grievances. Choper's empirical argument that adjudicating claims of this sort weakens the Court's ability to protect civil liberties seems entirely speculative and out of touch with the flow of our constitutional history. ${ }^{20}$

Viewed in its entirety, though, Choper's "nonjusticiability" reformulation appears deceptively harmless. Existing doctrine imposes few federalism constraints upon Congress in full recognition that the states' interests are adequately represented in the political process; ${ }^{21}$ Choper simply moves this political representation premise from the substantive to the "jurisdictional" level. The operational consequences of the shift may alter the results in a few marginal cases. Is this all, therefore, simply much ado about nothing? I think not. What makes Choper's formulation critically important is his effort to extend similar arguments of structure and prudence to the area of separation of powers, where the force and fit of those arguments are open to serious doubt. ${ }^{22}$

${ }^{19}$ See Monaghan, supra note Ir, at 39-43. The "federalism" issues currently decided by the Court involve the reach of federal statutes. However "explosive" their potential, even under Choper's proposal they must be adjudicated by the Court.

${ }^{20}$ In Oregon v. Mitchell, 400 U.S. II2 (1970), a badly divided Court invalidated an act of Congress reducing the voting age in state elections to 18 years. Within six months, the 26 th amendment, designed to overturn the decision, was submitted by Congress to the states and ratified. I am not aware that the Court suffered any loss of institutional prestige as a result of this expeditious overruling of one of its federalism decisions.

21 In Massachusetts v. United States, 435 U.S. 444 (1978), Justice Brennan's plurality opinion acknowledged that although National League of Cities "rejects the argument that the operation of the political process eliminates any reason for reviewing federalism-based challenges to federal regulation of the States qua States, . . . the existence of 'political checks' [is relevant] to a determination of the proper scope of a State's immunity from federal taxation." Id. at $456 \mathrm{n}$.I3 (emphasis in original).

22 The linkage to the separation of powers area is interesting in more ways than one. Numerous writers have noted that the concentration of actual political power in the national government under "Our Federalism" was a precondition to the concentration of national governmental power in the President. See P. KuRLAND, WATERGATE AND THE CONSTITUTION 156-57 (1978); Corwin, The Dissolving Structure of Our Constitutional Law, 20 WASH. L. REV. I85, I92 (I945), reprinted in E. Corwin, Presidential Power and the Constitution I4r, I49 (R. Loss ed. I976). 


\section{B. Separation of Powers: The Politics of Countervailing Power}

Choper's complex and intriguing chapter on separation of powers proposes that the Court "should not decide constitutional questions concerning the respective powers of Congress and the President vis-à-vis one another" (p. 263). I will confine my remarks to perhaps the most important area in which the thesis is applied: claims of constitutional authority made by the President in a domestic context. Choper's nonjusticiability approach has strong roots in the actual pattern of our constitutional history. Until the Nixon presidency brought frequent litigation of constitutionally based presidential claims, these claims most often appeared as political - and not legal weapons employed by Presidents in their bargaining with Congress. Few expected that these claims would be litigated before judges, and they seldom were.

Seldom - but sometimes. Historically, the Court has passed upon two different kinds of presidential claims of constitutional prerogative. The first, so far relatively rare, centers on presidential claims to "make law" without statutory authorization, or even in contravention of statute. The Steel Seizure Case ${ }^{23}$ is the paradigm for this class of cases. ${ }^{24}$ The second category involves congressional legislation that assertedly interferes with a specific zone of presidential power (for example, the appointments power), ${ }^{25}$ or more generally, that apparently impinges on the integrity or autonomy thought to be reposed in the presidency by article $\Pi .^{26}$ Myers $v$. United States ${ }^{27}$ remains the paradigm here.

Professor Choper now proposes to exclude both kinds of

${ }^{23}$ Youngstown Sheet \& Tube Co. v. Sawyer, 343 U.S. 579 (1952) (holding seizure of steel mills beyond presidential authority).

${ }^{24}$ Generally, as the Steel Seizure Case illustrates, the presidential claims of power are not located in a "specific" clause, but are said to be the inherent result of aggregating general clauses like the grant of executive authority, U.S. CoNST. art. II, $\S \mathrm{I}$, the commander-in-chief power, id. $\S 2$, and the duty to take care that the laws are enforced, id. § 3. See Monaghan, Presidential War-Making, B.U.L. REv., Spring I970, at 19,22 (special issue). Occasionally, the President can point to a clause with obvious and specific relevance to the issue. See, e.g., Ex parte Garland, 7 I U.S. (4 Wall.) 333 (I867) (presidential pardon nullified penalties imposed by an important federal reconstruction act).

25 U.S. CoNST. art. II, § 2.

${ }^{26}$ See generally Nixon v. Administrator of Gen. Servs., 433 U.S. 425, 439-55 (1977).

${ }^{27} 272$ U.S. 52 (I926) (President can remove a postmaster, a purely executive official, at will). See also Humphrey's Ex'r v. United States, 295 U.S. 602 (I935) (Federal Trade Commissioner, as a quasi-judicial and quasi-legislative official, may be removed by the President only on grounds specified by Congress). 
claims from the purview of "the judicial power." While courts could still adjudicate cases in which the President relies solely upon statutory authority for his conduct, they could not do so if, instead, the President asserts a constitutional prerogative, whether flowing from a specific power granted by article II, or one claimed to be "inherent" in the presidential office. Moreover, the shape of the presidential claim is crucial, for the Court may determine whether Congress has forbidden the President's conduct, if, as in the Steel Seizure Case, the President concedes the effectiveness of such a prohibition.

Is the justification for adopting Choper's proposal persuasive? Insofar as it rests upon a feared weakening of the judicial power in the civil liberties area, I am again unpersuaded. No evidence exists that modern, highly publicized separation of powers cases have diminished the Court's prestige. Quite the contrary; in both the Steel Seizure and the Watergate Tapes cases, ${ }^{28}$ the Court added to its institutional capital. ${ }^{29}$ Choper's largely nineteenth century historical reference cannot support his late twentieth century functional analysis. Consequently, Choper's position must ultimately stand or fall on the strength of presidential claims of constitutional prerogative in the context of the dynamics of the political process.

Choper's structural argument in this setting cannot rest on the same premises advanced to justify complete judicial withdrawal of protection from the states against Congress. Nonjusticiability in the federalism area was grounded in the perception that the states are represented in the national political process. . Plainly, Congress is not institutionally "represented" in the White House. For Choper, therefore, the protective dynamic is quite different: the model is one of countervailing power, with each side armed with formidable "weapons" to protect its turf (p. 275). Choper elaborates on the congressional armaments: refusal to enact legislation, including appropriations; refusal to confirm appointments; and impeachment (pp. 28I-86). ${ }^{30} \mathrm{He}$ does not list the power to pass legislation forbidding the presidential conduct, an important weapon unless the President's claim is that either a specific

${ }^{28}$ United States v. Nixon, 4 I8 U.S. 683 (I974).

${ }^{29}$ Nor does the Court appear to have weakened its position in passing upon separation of powers in a less politically charged atmosphere. See, e.g., Buckley v. Valeo, 424 U.S. I, Iog-43 (I976) (invalidating congressional exercise of the appointments power).

${ }^{30}$ Moreover, Choper observes that the presidency is restrained by other "checks," including the bureaucracy, outside interest groups, and the electorate (pp. 276-8I, 3II-I4). 
clause or his "inherent" power permits him to disregard even an express statutory prohibition.

In the face of these congressional weapons, the risk of a President's continually riding roughshod over the legislative branch appears to be quite slim. Indeed, the relevant historical experience demonstrates the "fortunate fact" that potential "constitutional crises" between Congress and President have yielded to the give and take of the political process (pp. 29899). ${ }^{31}$ The hard fact is, after all, that no President can accomplish very much for very long in the absence of congressional concurrence (p. 368).

Choper's nonjusticiability conclusion, however, generates more serious risks in the separation of powers area than in the federalism area. Perhaps, as Choper believes, few Presidents will be bold enough to claim an "inherent" power of lawmaking so expansive as to permit them to disregard an express statutory command. Thus, the President's usual claim will be that his action is not legislatively forbidden and that he has authority to proceed until Congress acts to the contrary. Whether, in a period - unlike the nineteenth century - of extensive statutory law, courts will be able to distinguish meaningfully between unauthorized and forbidden presidential conduct remains to be seen. ${ }^{32}$

But even if executive claims are so limited, Choper's view sanctions an enormous shift in political power from Congress to the President. His nonjusticiability doctrine requires that a court treat the presidential claim as establishing legal norms that are enforceable by appropriate judicial orders even against private parties. ${ }^{33}$ For practical purposes, the Court would

31 "[H] $]$ istory and experience" teach that "pitched battles . . . arise only infrequently ... . [O]ur political scheme has worked" (pp. 286-87).

${ }^{32}$ Cf. AFL-CIO v. Kahn, 618 F.2d 784 (D.C. Cir.) (en banc) (court of appeals strained to find sufficient statutory authority for the President's price control program), cert. denied, 443 U.S. 915 (I979), discussed in Case Comment, Using Federal Procurement to Fight Inflation, 93 HARv. L. REV. 793 (1980).

${ }^{33}$ Thus Choper writes that

in the renowned case of In re Debs - in which the United States sued in federal court to prevent union officials from obstructing interstate railway and mail transportation - as well as in the widely publicized more recent decision in United States v. Brand Jewelers, Inc., the government obtained an injunction against private individuals despite the fact that no act of Congress had expressly declared the conduct in which they had engaged to be unlawful. In effect, the executive was itself "enacting" law as well as "enforcing" it . . . . [Although the rationale was not correct,] there was no dispute that Congress had the power to make the enjoined conduct unlawful . . . [and] the Court should have held the issue to be nonjusticiable and granted the injunction accordingly. (Pp. 320-2I) (emphasis added) (footnotes omitted).

I do not think that either cited case supports Choper's thesis. In re Debs, 158 U.S. 564 (1895), and United States v. Brand Jewelers, Inc., 318 F. Supp. 1293 (S.D.N.Y. I970), have conventionally been understood as involving only the question 
treat the presidential claim as substantively valid, even though it does not "legitimate" it. Choper insists (p. 323) that this startling proposal cannot fairly be impeached by imaginary horribles that would never materialize, like presidential tax codes. But Choper's proposal is likely to affect several important areas. Arguably, the President has already "enacted" both a price and wage control ${ }^{34}$ and an affirmative action code ${ }^{35}$ without adequate statutory authorization. In Choper's view, the courts would be compelled to enforce both by injunction simply on the President's word. Under this view we need no longer worry whether the Court has gone too far in sustaining wide-open congressional delegations to the President; ${ }^{36}$ no delegation at all is needed.

Choper's nonjusticiability doctrine, therefore, could significantly shift political power by bestowing the advantage of inertia on presidential policy determinations. Congress would need to act affirmatively to overturn any presidential code, a difficult task made even more so by the virtual certainty of a presidential veto. ${ }^{37}$ If unable to override the veto, Congress

of the right of the Executive to sue without statutory authority - not as recognizing a presidential power to fashion the substantive law. See, e.g., United States v. Mattson, 600 F.2d I295, I298-30r (9th Cir. 1979) (refusing to follow Brand Jewelers on the right-to-sue issue). In Brand Jewelers, no act of Congress or executive order was needed to make the practice of "sewer service" illegal; the court believed both the I4th amendment and the negative impact of the commerce clause provided the basis for standing to sue. 3 I $8 \mathrm{~F}$. Supp. at 1295 . But whatever the status of Debs on the right of the executive to sue without statutory authority, its substantive theory, an erroneous one, seems to be that the President was simply enforcing independent substantive norms derived ${ }^{-}$from the commerce clause, various federal statutes, and public nuisance doctrine in obtaining an injunction against the Pullman strike. See generally United States v. Mattson, 600 F.2d at I298.

${ }^{34}$ See note 32 supra.

35 Many of the current federal affirmative action programs rest upon Exec. Order No. $I 1,246,3$ C.F.R. 339 ( $1964-1965$ Compilation), as enlarged by Exec. Order No. II,375, 3 C.F.R. 684 (Ig66-I970 Compilation), dealing with government employment and government contracts. In Chrysler Corp. v. Brown, 44I U.S. 28I (I979), the Court observed that the "origins of the congressional authority for Executive Order II246 are somewhat obscure and have been roundly debated by commentators and courts." $44 \mathrm{I}$ U.S. at 304 . In his concurrence, Justice Marshall noted that the Court did not decide that the executive order "must be founded on a legislative enactment." Id. at 320. See generally Brody, Congress, the President, and Federal Equal Employment Policymaking: A Problem in Separation of Powers, 6o B.U.L. REv. 239 (I980).

${ }^{36}$ For a discussion of the delegation doctrine, see J. ELx, DEMOCRACY AND DistruST I31-34, I77 (I980); P. KURLAND, supra note 22, at I75-76.

37 Whatever the range of "inherent" executive power, the President obviously plays an enormous role in actually shaping domestic policy because of his veto power, by which he can force Congress to acquiesce in his views. See B. ECKHARDT \& C. BLACK, supra note 5, at 57-65; Black, Some Thoughts On The Veto, LAW \& ConTEMP. PROB., Spring 1976, at 87 . 
would then have to resort to other weapons, such as a refusal to appropriate funds, in order to reclaim its authority over national policy. Perhaps, as Choper believes, it would all work out in the end. That seems a heroic assumption.

Like Choper, I do not believe that judges have a significant role to play in holding the President within his constitutionally prescribed domain. ${ }^{38}$ Over the long haul, only Congress itself can prevent real diminution of its power. But I am unwilling to see the Court augment presidential power by a nonjusticiability doctrine that in effect validates virtually every claim of inherent presidential authority. ${ }^{39}$ Choper observes that few such claims have been made. That is hardly surprising given the existing state of the law, particularly after the Steel Seizure Case. But if Choper is followed will that pattern endure long? Can the Solicitor General ever fail to argue that the President's conduct is statutorily authorized, or, in the alternative, is supported by his inherent authority when not positively forbidden by statute? Indeed, sooner or later I would expect the President to insist upon an "inherent" power to disregard even statutes when his view of the "national interest" so dictates. ${ }^{40}$

Choper's nonjusticiability approach is flawed in another respect: it will not have the "public relations" value he seeks. Choper's fear is that adjudication of separation of powers claims weakens the Court's ability to protect individual liberties. Will the public really understand the difference between holding that a presidential claim is unauthorized by statute and holding that it is forbidden by statute? Or, more important, the difference between treating a claim as valid and judicially enforceable and treating it as nonjusticiable but still enforceable? I doubt it. There is certainly very little evidence

\footnotetext{
${ }^{38}$ In this respect, Choper rightly notes that judicial decisions have augmented executive power as often as not (pp. 314-15).

${ }^{39}$ While he may overstate the case, see Lacovara, Watergate: Next Time, Will We Be So Lucky?, 88 YALE L.J. 659 (x979), Professor Kurland argues that Watergate was the result not of "bad men," but of the unjustified aggrandizement of institutional power in the presidency. See P. KuRLAND, supra note 22, at $180-83$. For a discussion of the statutory power that accrues to the President when he declares an "emergency," see Note, The National Emergency Dilemma: Balancing the Executive's Crisis Powers with the Need for Accountability, 52 S. CAL. L. REv. 1453 (1979).

${ }^{40}$ Space limitations preclude extensive treatment of Choper's discussion of the "direct conflict" problem. The presidential claim is nonjusticiable; so, too, is the congressional claim of constitutional power embodied in statute. Essentially, Choper advocates a "hands-off" policy, with the Court not enforcing the position of either side: "This leaves matters as they were before the Court's process was invoked ..." (p. 354). His elaboration of this thesis creates problems for me. Using a handsoff approach, I do not see why a statutory assignment of duties should prevail over a presidential effort to assign duties to a different official (pp. 349-50). Nor do I see why a confiscatory statute should prevail over a presidential pardon (pp. 350-5I).
} 
that the public understands in any detail what the Court does. Moreover, so far as I can tell, the man in the street has only one criterion: Does he like the substantive result? He shows very little interest in institutional or process matters and no interest at all in the "legalistic" distinction drawn by Choper. In fact, it seems more likely that Choper's recommended holding of nonjusticiability conveys to the man in the street a message of impotence, a message designed to weaken the Court and diminish its prestige. In short, there seems to be no empirical support for the assumptions about public attitudes toward judicial work that underlie Choper's nonjusticiability doctrine.

\section{Nonjusticiability and Legitimacy}

To criticize Choper is not, however, to escape his challenge: Does judicial review serve any function in federalism and separation of powers cases? In many cases of directly conflicting assertions of power, some decisionmaker must declare a winner. In the Watergate Tapes cases ${ }^{41}$ for example, it is difficult to imagine what would have been the consequence had the Court refused to hold for one party or the other, but one can hardly escape the conclusion that the toll - both in lost public confidence in government and in inability of the Executive and legislature to work together - would have been heavy. Beyond that issue, a more important one remains: How necessary is a judicially developed substantive theory for cases involving questions about the appropriate constitutional allocation of power? In the federalism area, Choper's nonjusticiability thesis can, as I have said, be restated in substantive terms: The Constitution remits the states to the political process to protect their interests, and the legitimacy of expansive exercises of federal power therefore rests on state consent. But in the separation of powers area no such reformulation is possible. Thus, we are left with the question whether we need a substantive theory of presidential power, a theory that is not the indirect product of notions of political conflict and nonjusticiability. Whether the President had authority to seize the steel mills in Youngstown, to resist the subpoenas in Nixon, and to fire his postmaster in Myers are important questions involving claims of constitutional right, not power. Is there a need for a judicial ruling on the constitutional legitimacy of the authority claimed by the President? Choper minimizes that need, despite his elaborate demonstration that Supreme

${ }^{41}$ For discussion of the various cases, see P. KurLAND, supra note 22. 
Court decisions have a practical impact on the choices made by other governmental actors.

Final evaluation of Choper's approach in the separation of powers area must await the refinement of "legitimacy" theory. ${ }^{42}$ His nonjusticiability theory alleviates the traditional fears that the Supreme Court will illegitimately usurp political power ${ }^{43}$ but leaves the other participants in the constitutional scheme without any source of judicial guidance on the legitimacy of their own actions. In a society in which judicial declarations as to substantive constitutionality have increasingly become a touchstone of legitimacy, ${ }^{44}$ a sudden refusal by the judiciary to continue its canonical role would be disquieting. The precise effect of the abandonment of this traditional judicial role can be only a matter of speculation until further study is made of the legitimacy of Court action in setting guidelines for other political organs.

\section{III.}

Choper's view that the central role of the Court is to protect individual liberties is a widely shared premise of modern constitutional theory. ${ }^{45}$ Once again, Choper's approach is tied to the political dynamics of "Our Democracy." He begins by narrowing his claim: neither federalism nor separation of powers claims sharply threaten individual liberties because, in the end, the restriction could be imposed by some appropriate political organ. Quite plainly, however, the actual allocation among various governmental actors of the power to restrict

\footnotetext{
42 I doubt whether one can reason very clearly about the role of the Supreme Court on the basis of perceptions, real or imagined, of popular reaction to the Court's decisions. While that factor may have a role at the margins in a comprehensive theory of judicial review, it plays too great a role in the theories of Choper and other commentators. See, e.g., A. BICKel, The LeAST Dangerous Branch (I962); C. Black, The People and the Court 56-86 (1960). To the extent that legitimacy theory focuses upon the problem of the appropriate "audience," my inclination is to think in terms of elite theory. The Court's conduct must appear generally legitimate to the judges, professors, and lawyers who follow its conduct. See sources cited in Monaghan, supra note $\mathrm{I}_{5}$, at $\mathrm{I}_{363}$ n.3. See also Hart, The Supreme Court, 1958 Term - Foreword: The Time Chart of the Justices, 73 HaRv. L. REv. 84, ror (1959) (Court losing respect of "first-rate lawyers").

${ }^{43}$ See L. Tribe, American Constitutional Law § I-8, at if (i978) (discussing worry about judicial legitimacy).

44 This phenomenon has been signaled in part by the decline of the political question doctrine in domestic matters. See Henkin, supra note 7 , at 617-25; cf. Goldwater v. Carter, 444 U.S. 996, 1002-06 (1979) (Rehnquist, J., concurring in the judgment) (foreign affairs).

${ }^{45}$ See United States v. Carolene Prods. Co., 304 U.S. I44, I52 n.4 (1938); J. ElY, supra note 36, at 73-I04. See also L. TRIBE, supra note 43, at v.
} 
liberty is an important aspect of the overall dynamics of a system of civil liberties. ${ }^{46}$ But Choper's general position is, at least in 1980 , a strong one. Few modern separation of powers violations clearly implicate individual liberty. ${ }^{47}$ With respect to federalism, the matter is, perhaps, less clear. ${ }^{48}$ Marching under such banners as "Participatory Democracy," many democratic theorists have urged greater decentralization of authority because large, remote, unresponsive governments diminish the political liberty and equality of the citizen. ${ }^{49}$ For both the Supreme Court and Choper, nothing in the constitutional structure of "Our Federalism" forbids that decentralization.

Less satisfactory is Choper's justification of judicial protection of individual liberties against all governmental intrusion. We are told that the "predominant pattern" (p. 68) of our history confirms Madison's belief that "invasion of private rights is chiefly to be apprehended, not from acts of Government contrary to the sense of its constituents, but from acts in which the Government is a mere instrument of the major number of its Constituents" (pp. 60-6I). ${ }^{50}$ Perhaps so. ${ }^{51}$ But we are still left with the important questions of which "private rights" should be protected, by which organs of government, and at what level of intensity. ${ }^{52}$ Judicial scrutiny of legislation having a specially burdensome impact on discrete and insular minorities, an approach articulated in United States $v$. Caro-

${ }^{46}$ See J. ELY, supra note 36 , at $90 ;$ L. TRIBE, supra note 43 , $\$ \S$ I7-1 to -3 . See also Comment, The Bounds of Legislative Specification: A Suggested Approach to the Bill of Attainder Clause, 72 YALE L.J. 330, 343-48 (1962) (arguing that bill of attainder clause reflects the Framers' concern that legislative power be checked).

${ }^{47}$ Choper notes the historical connection of separation of powers with liberty concerns (pp. 263-70): differentiation of power was thought to contribute to liberty. See P. KuRLAND, supra note 22, at r6o. Choper observes that the historical fear was of legislative, not executive power, and that in this context judicial review did not figure prominently as a mechanism for control. He omits any discussion of the role of the jury as a separation of powers mechanism: the jury further diffused authority because any governmentally imposed sanction would almost certainly be by way of a criminal prosecution and that needed the concurrence of 12 citizens. The growth of federal equity jurisdiction and the explosion of administrative law greatly reduce the role of the citizen in controlling the imposition of sanctions.

${ }^{48}$ Choper's careful review (pp. 24I-54) shows that the Framers supported federalism at least as much to achieve governmental efficiency as to protect individual liberty.

49 J. Lively, Democracy I3I-45 (I975); M. Margolis, Viable Democracy 170-73 (1979); C. PATEMan, PARTicipation AND Democratic TheORY (I970).

${ }^{50}$ Quoting 5 The Writings of James Madison 269 (G. Hunt ed. Ig04).

si See generally J. ELY, supra note 36, at 73-179.

$52 \mathrm{We}$ are, of course, concerned only with the judicial role. Political scientists have long understood that there are numerous other mechanisms for protecting against majoritarian tyranny. See R. DAHL, A PREFACE to Democratic TheORY I7-I9 (I956). 
lene Products Co. ${ }^{53}$ rests on a premise that, while "Our Democracy" contemplates an open political process, these groups have been excluded. But may judges go further and posit fundamental "rights" having no basis in the constitutional text or structure simply because they believe that a "just" constitutional order should guarantee those "rights" against the "majoritarian political process"? Can courts legitimately constrain the outcomes of a fair and open political process by externally derived principles of political morality? This question stands at the very center of recent constitutional theory ${ }^{54}$ and Professor Choper's failure to discuss the implications of a pragmatic view of "Our Democracy" in this context (see pp. 73-75) leaves me quite uncertain about the reach of his conception of the judiciary's role in protecting civil liberties.

Moreover, any effort to ground judicial protection of individual liberties in a fear of the majoritarian political process needs some qualification. Currently, at least, that process is not insensitive to claims of individual rights and liberties. Quite the contrary. The vast bulk of rights and liberties possessed by the citizens of the United States are the product of that political process. ${ }^{55}$ Acting under its commerce and spending powers, and the Civil War amendments, Congress has established a range of rights and liberties far beyond the constitutional minimums. ${ }^{56}$ So, too, have many states.

On the other hand, I think one can underestimate the need to protect certain rights of the "majority," particularly political rights. This underestimation is rooted in uncertainty about the whole concept of the "majoritarian political process." Modern constitutional theory implicitly views that concept through the lens of pluralism or interest-group theory. ${ }^{57}$ But a strong tradition in political sociology tracing back to Mosca and Pareto suggests that this presents a distorted image. 58 Whatever the form of government, "[i]n all societies ... two classes of people appear - a class that rules and a class that is ruled. The first class, always the less numerous, performs

53304 U.S. $144, \times 52$ n.4 (r938).

${ }^{54} \mathrm{See}$ J. ELY, supra note 36, at 105-34; Tribe, The Puzzling Persistence of ProcessBased Constitutional Theories, 89 YALE L.J. 1063 (1980).

55 For statutory references, see P. Freund, A. Sutherdand, M. Howe \& E. Brown, Constitutional LaW 135-44 (H. Monaghan ed. Supp. 1980).

56 Choper recognizes this fact (p. 68) but gives it inadequate weight. I am, of course, prepared to give credit to the Supreme Court for its role in educating the political process to the need for protecting civil liberties.

57 Choper follows this tradition, observing that the majority at any one time is simply the product of shifting and differing combinations of minorities (pp. 44-45).

${ }^{58}$ See G. Mosca, The Ruling Class (A. Livingston ed. \& H. Kahn trans. I939); 3 V. Pareto, The MIND and Society §§ 2026-2059 (Dover ed. 1935). See generally PARETo \& Mosca (J. Meisl ed. I965). 
all political functions, [and] monopolizes power ...."59 On this view of the political order, so-called "elite" theories of democracy have surfaced. In substance, these theories urge that the core of a democratic political order is not majority rule but an ongoing sense that the rulers are "on probation" - that is, they can be held accountable for their rule and periodically divested of their ruling authority. ${ }^{60}$ Interest group and elite theory have some common consequences for judicial review in "Our Democracy." Suffice it here to say that to the extent that elite theory provides a valid account of the practical operation of our political system, ${ }^{61}$ constitutional protection for at least the political liberties of the majority is necessary if the majority is to succeed in holding its "governors" accountable. ${ }^{62}$

In the end, the Court is but one mechanism — an important one, to be sure - operating in our system of civil liberties. Its precise role within that system is a perennial problem. Although Choper may be correct that protection of individual liberties is the Court's most important obligation, he does not provide us with a sufficiently theoretical and comprehensive description of the judicial role. Still, he rightly reminds us that any comprehensive theory must take account of the shortcomings of our "majoritarian" political process.

\section{IV.}

Despite my doubts and disagreements, this comprehensive and complex book is deeply thought provoking. The ultimate test of the book is its capacity to stimulate reexamination of fundamental matters. Measured against that standard, Choper's book gets high marks.

${ }^{59}$ See G. MoscA, supra note 58 , at 5o. Robert Michels generalized this into an "iron law of oligarchy," a theory that holds that all organizations are eventually taken over by self-perpetuating elites. R. Mrchels, Political Parties (Free Press ed. 1962).

60 The classic exposition is of course J. Schumpeter, Capitalism, Socialism AND DEMocracy (3d ed. I950). Schumpeter attempted to redefine "democracy" as "that institutional arrangement for arriving at political decisions in which individuals acquire the power to decide by means of a competitive struggle for the people's vote." Id. at 269 .

${ }^{61}$ For an informative introduction to the subject, see K. PREwITT \& A. STONE, The Ruling Elites (r973).

${ }^{62} \mathrm{~A}$ recent article by Professor Blasi reflects a trace of this view. He notes that the development of free speech doctrine has been triggered by the claims of minority groups for input into decisionmaking, but he speculates that in the future the first amendment will be seen more as a mechanism by which the misuse of government power can be checked by those "powerful persons, representatives of movements and institutions that in a realistic sense do serve as counterforces to government." See Blasi, "Joumalistic Autonomy" as a First Amendment Concept, in IN HONOR oF JUSTICE DOUGLAS 55, 68 (R. Keller ed. I979). 
Rules of the Supreme Court of the United States. Washington: U.S. Government Printing Office. Adopted April I4, I980; Effective June 30, I980. Pp. ii; 78. Free. ${ }^{1}$

\section{Reviewed by William H. Allen ${ }^{2}$ and Alex Kozinski ${ }^{3}$}

Twentieth century procedure has come slowly to the highest court in the land, but come it has. Here as elsewhere, the vestiges of tradition have given way to the demands of efficient administration. Gone and unlamented are the admission of all applicants to the Bar in open court and the writ of certiorari to correct diminution of the record. So long gone that none of us remember them are the days of unlimited oral argument, and even the days when the customary argument was an hour per side are fading from memory. Moreover, although the tradition of delivering opinions in open court is retained, the oral opinions more often than not are quite perfunctory and not the full-blown opinions of yesterday. In this latest revision of its rules, the Supreme Court has taken further steps to bring its practice into the modern era already populated by the lower federal courts. To those, however, who have felt an arcane attachment to the more gentlemanly aspects of Supreme Court practice, which allotted practitioners freedoms - and attendant risks - not enjoyed in other federal courts, the day on which the new rules went into effect, June 30 , 1980, was one tinged with nostalgia.

The new rules arrived with little fanfare. They had the immediate effect of depreciating every practitioner's investment in that authoritative manual of Supreme Court practice, Stern and Gressman. ${ }^{4}$ On the other hand, the new rules generally clarify what was previously obscure procedure and make explicit what lawyers who frequently practice before the Court have known to be required, expected, or at least preferred form. They are therefore a further welcome step toward codification of the "common law of procedure" referred to by former Attorney General Garland at the turn of the century. ${ }^{5}$

No longer need the new Supreme Court practitioner puzzle,

1 Single copies of the rules may be obtained at no charge from the Clerk of the Court. Multiple copies can be obtained for $\$ 2.50$ each from Commerce Clearing House by reference to document number 5175 . The rules are also reported at 85 F.R.D. 435 ( 1980$)$.

2 Member, District of Columbia Bar.

${ }^{3}$ Member, California and District of Columbia Bars.

${ }^{4}$ R. Stern \& E. Gressman, Supreme Court Practice (5th ed. 1978).

5 A. Garland, Experience in the Supreme Court of the United States, With SOME Reflections aNd Suggestions as to that Tribunal I2 (1898), quoted in R. STERN \& E. GRESSMAN, supra note 4, at 18. 
for example, over the way to set up the cover of his brief. New rule 33.2(a) provides a veritable blueprint for "[a]ll documents filed with the Court," thereby rendering unnecessary resort to the briefs of more experienced colleagues for use as models. From the top of the page, where the number of the case appears (or where a space is left, when the document initiates a case), to the bottom, where the designation of the attorney of record must be given, the rule enumerates all items that must appear and specifies their order. The new rule finally settles a question of style that has long divided Supreme Court practitioners: Where does the case number go? While many, including the office of the Solicitor General, have followed the now required practice of placing the case number first, other members of the Bar, including no less a Supreme Court practitioner than Dean (and former Solicitor General) Griswold, have placed the number third, following the name of the Court and its Term. The new rule is a vindication of the former approach.

Regrettably, some other points have not received such elegant treatment. The very same rule 33.2(a), for instance, requires that "the name, post office address, and telephone number of the member of the Bar of this Court who is counsel of record for the party concerned" must appear on the front cover. Quite apart from the novel idea that a telephone number be stated on a Supreme Court brief, the rule is notably unhelpful in providing that, when more than one counsel is listed on the cover, "counsel of record shall be clearly identified." Nowhere do the rules specify just who qualifies as "counsel of record." 6 Nor do they suggest how he or she is to be designated; th. only idea that suggests itself, placing an asterisk next to the name of one attorney and using a footnote on the front cover to designate him as the counsel of record, can hardly be viewed as consistent with the otherwise elegant lines of the cover. ${ }^{7}$

Probably the most drastic change in the rules is the imposition of page limitations on briefs. The old rules, which placed no such constraints upon petitions, jurisdictional state-

6 The only hint appears to be the phrase "and upon whom service is to be made" following the term "counsel of record." This might mean that counsel of record is the attorney to whom service copies are to be provided by the opposing party. However, from the phrasing of the rule, receipt of service appears to be merely an incident of being counsel of record, rather than the full measure of that office.

7 In practice the identification requirement has been ignored by many, including the office of the Solicitor General. See, e.g., Brief of the United States and the Federal Respondents, Upjohn Co. v. United States, No. 79-886 (U.S., filed Sept. II, I980) (seven Department of Justice attorneys listed, none designated as counsel of record). 
ments, and briefs on the merits, made the Court unique among the federal appellate courts. ${ }^{8}$ Perhaps because of the burden imposed on the Court by lawyers pursuing this freedom, the new rules set strict page limits for these documents. Thirty pages are granted for jurisdictional statements, motions to dismiss or affirm, and petitions for certiorari and responses thereto (rules $15.3,16.3,21.4,22.2$ ); fifty pages for briefs on the merits (rule 34.3 ); twenty pages for amicus briefs pertaining to petitions for certiorari or jurisdictional statements (rule 36. I); and so on. ${ }^{9}$

It would appear that the Court is serious about these page limits. Unlike some other procedural rules, such as the time for filing briefs on the merits, which may be waived by the Clerk alone, a motion for enlargement or waiver of the page limits may be granted only by the Court or a Justice, upon motion submitted at least fifteen days before the filing date. Moreover, "such an application is not favored" (rule 33.4). ${ }^{10}$ While the rule apparently reflects the Court's impatience with briefs that are too long, one wonders at the wisdom of blanket page limitations that can be enlarged only through the cumbersome procedure of a motion to a Justice or the Court. Although a page limitation may make some sense with respect to petitions for certiorari and jurisdictional statements, once the Court has decided to grant plenary review, it should be left to counsel to determine in the exercise of their professional judgment how best to walk the precarious line between conveying a full understanding of their case and losing the reader's

8 See FED. R. APP. P. 28 (g).

9 Rule 33.3 converts these page limits for briefs produced by photostatic reproduction of typed copy. Any resourceful counsel who would attempt to circumvent the limits on typed pages by techniques such as setting margins farther toward the edge of the page, one-and-a-half spacing, and the use of a typewriter with an unconventionally small typeface should first take note of the provisions of rule 33.I(c) (requiring pica type and double spacing) and 33.r(d) (3/4-inch margin on all sides). Although the assistant clerk in charge of these matters has confessed that he does not take a ruler to each document to police compliance, the document must at least look good to the eye and appear to be in general compliance with the rules. Telephone Conversation with Assistant Clerk, United States Supreme Court (Oct. x5, 1980).

All of these page limits are exclusive of the subject index, table of authorities, verbatim quotations, and any appendices. In addition, summaries of argument are apparently not being counted toward the page limits. See, e.g., Brief of Northwest Airlines, Inc., Northwest Airlines, Inc. v. Transport Workers Union, No. 79-1056 (U.S., filed Aug. 29, I980) (53 pages of argument plus three of summary); Brief of the United States and the Federal Respondents, Upjohn Co. v. United States, No. 79886 (U.S., filed Sept. II, I980) (44 pages plus seven of summary).

${ }^{10}$ The I5-day requirement makes this rule particularly burdensome since few lawyers prepare briefs sufficiently in advance to be able to predict the number of pages more than two weeks before the filing deadline. 
attention by burdening him with trivialities. In any event, one suspects that whatever judicial time is saved by shorter briefs may be lost in considering and ruling on motions for extension of the page limits.

Although it can be argued that similar page limitations have worked well in the courts of appeals, ${ }^{11}$ cases that have been selected for plenary review by the Supreme Court are likely to be more complex, and certainly more important to the development of the law, than the run of the mill appellate case. That, at least, has been the rationale by which the Bar has been willing to endure unflinchingly the recent proliferation of Supreme Court decisions containing lengthy explications of each Justice's particular view of the case. ${ }^{12}$ It can only be hoped that, as a quid pro quo for the new page limitations, the Justices will endeavor to introduce into their opinions the terseness they now demand of counsel and avoid filling the pages of the United States Reports with essays reflecting pet interests that have little or no relation to the question for decision. ${ }^{13}$

These changes, particularly the strict page limitations, reflect the changing relationship between the Court and its Bar. Many items heretofore left to the discretion of the Supreme Court practitioner, with the gentlemanly understanding that the privilege would not be abused, are now consigned to rule. Perhaps because so many more lawyers are admitted to practice before the Court than ever before, the Justices believe this type of standardization is necessary.

One such standardizing change that is particularly saddening is rule $33.2(\mathrm{~b})$, which specifies the color of the covers of printed documents. Under this provision, jurisdictional statements and petitions for certiorari are to be covered in white; responses to petitions and jurisdictional statements, in light orange; briefs on the merits, light blue, light red, and yellow; intervenor or amicus briefs, green; and so on. ${ }^{14}$ By specifying

11 However, no one knows how frequently motions for enlargement of page limits are made in the courts of appeals, and in our experience they are seldom denied.

${ }_{12}$ See, e.g., Fullilove v. Klutznick, No. 78-1007, slip op. (U.S., July 2, 1980) (five opinions totaling Io7 pages); Regents of the Univ. of Cal. v. Bakke, 438 U.S. 265 (r978) (six opinions totaling 156 pages); Buckley v. Valeo, 424 U.S. I (1976) (six opinions plus appendix totaling 294 pages); Furman v. Georgia, 408 U.S. 238 (1972) (per curiam order plus nine opinions totaling 233 pages).

${ }^{13}$ See, e.g. , Smith v. Organization of Foster Families for Equality \& Reform, 43I U.S. 816, 823-38 (x977); Flood v. Kuhn, 407 U.S. 258, 260-64 (1972).

${ }^{14}$ Curiously enough, in this kaleidoscope of colors, no provision was made for briefs in opposition to motions to dismiss or affirm, or supplemental briefs, each of which is specifically authorized by the rules. See rules $16.5, .6,22.5, .6,35.5$. Presumably these fall within the catchall provision of the rule, which provides for a 
not only the color but also the shade to be used, the new rule will put an end to the use of "firm colors," i.e., adoption by a firm of a particular color that is used on all of its briefs in the hope that it will come to be associated in the minds of the Justices with that firm. ${ }^{15}$ The new rule will also prevent other creative use of color such as that in Washington $v$. Washington State Commercial Passenger Fishing Vessel Association, ${ }^{16}$ a case involving fishing rights, where the briefs of petitioners, the Puget Sound Gillnetters Association et al., came appropriately attired in salmon pink.

In addition to these formal touches, the new rules contain some significant substantive changes. Petitions for writs of certiorari to review judgments in criminal cases must now be filed within sixty days after judgment, with a possible thirtyday extension obtainable from a Justice (rule 20.I). Under the old rule 22 , petitions had to be filed within ninety days of a state criminal judgment with a possible sixty-day extension, and within thirty days of a federal criminal judgment, with a possible thirty-day extension. Rules $\mathrm{I} 2.4$ and $\mathrm{I} 9.5$ now provide that cross-appeals or cross-petitions for certiorari may be filed a nonextensible thirty days after receipt of the original jurisdictional statement or petition. ${ }^{17}$ This change is truly deserving of praise, for it dispenses with the costly and frequently needless task of preparing a cross-petition or crossappeal and holding it ready for filing in case a petition or appeal should be filed by the opposing party at the last minute. ${ }^{18}$ The new rules also take away the additional twenty days given by the I970 Rules to the government to respond to

tan cover for all unspecified documents. On the other hand, it is possible that briefs in opposition to motions to dismiss or affirm will be considered akin to reply briefs, and therefore should bear yellow covers.

15 The rule does afford this luxury to the office of the Solicitor General, all of whose submissions are to be clad in gray. However, the Solicitor General in fact discontinued the use of the traditional gray cover some time ago, switching to a tan shade. Apparently valuing its own esthetic judgment over obedience to the new rule, that office continues to file briefs covered in tan. See, e.g., brief cited note 7 supra.

${ }^{16} 443$ U.S. 658 ( 1979 ).

17 However, a cross-appeal or cross-petition that is timely only because of these provisions may not be heard on the merits unless the Court accepts the case for plenary review on the timely filed appeal or petition of the opposing party (rules 12.4, 20.5).

18 Parties who have been formally designated respondents or appellees, but who in fact support the position of the petitioner or appellant, now have a nonextensible 20-day period in which to file any pleading (rules ro.4, 19.6). Reply briefs must now be filed at least one week prior to oral argument, rather than three days (rule 35.3). A petition for an extraordinary writ no longer need (but at counsel's discretion, still may) be prefaced by a motion for leave to file the petition (rule 27.r). 
petitions for certiorari and jurisdictional statements. ${ }^{19}$ Perhaps the Court found that the office of the Solicitor General was no more timely in filing responses under the fifty-day limit than under the thirty-day one.

The rules for filing and service of documents have also undergone some substantive changes. Rule 28.2 now provides that documents not received by the Clerk within the specified period are deemed to be timely filed if mailed within the time allowed for filing, provided that a notarized statement signed by a member of the Bar of the Court is filed with the Clerk, certifying and setting forth the details of the mailing. ${ }^{20}$ The old rules contained a limited mail-in procedure, applicable only in the case of petitions for certiorari to review federal criminal judgments originally arising in outlying district courts such as Guam or Alaska. ${ }^{21}$ Rule 28.4 (c), reflecting a statutory change, ${ }^{22}$ now requires service of process upon the attorney general of a state in any proceeding to which the state or its agents are not parties when the constitutionality of a state statute is called into question, much in the way the rules have long required service upon the Solicitor General when a federal statute was challenged (rule 28.4(b)).

The new rules also contain miscellaneous changes that clarify matters previously obscure, or codify practices already in existence. Rule 7 settles the meaning of the two-year prohibition on practice before the Supreme Court by law clerks and other court personnel, by specifying that this means "participat[ion], by way of any form of professional consultation or assistance, in any case before this Court" (emphasis added). ${ }^{23}$ Another question that has arisen from time to time is whether an amicus may file a reply brief. Rule 36.2 now answers this in the negative. The same rule also specifies that amicus briefs must identify the party whose position is supported. Rule 44.4 now specifies the items to be presented in an application for

${ }^{19}$ Compare old rule I6.I with new rules I6.I, 22.I. The new rules also delete the special treatment theoretically afforded to motions for oral argument by government amici curiae. Compare rule 38.7 with old rule 44.7. However, the Solicitor General, along with state and local government counsel, may still file amicus briefs without obtaining the consent of the parties (rule 36.4).

20 Use of the mail-in procedure requires use of the United States mails. Use of a private courier service will not secure the benefit of this rule. Indeed, it is not clear whether use of a commercial courier - as opposed to a special messenger who personally delivers the documents - can ever constitute effective service under this rule.

${ }^{21}$ See old rule 22.2.

${ }^{22}$ See 28 U.S.C. § 2403 (b) (I976).

${ }^{23}$ The rule extends this prohibition, previously applicable only to clerks and secretaries of Justices, to all Court personnel. 
a stay, which include a copy of the judgment or opinion to be reviewed and the order, if any, denying relief below. ${ }^{24}$

Among the changes that give official recognition to existing practice are rule 23.I, which specifies that the Court may dispose of cases on petition for certiorari by summary disposition on the merits, and rule 37.2 , which provides that cases will commence being called on the first, rather than the second, Monday of each Term. Similarly, rule 29.3 codifies the now accepted practice of seeking extensions of time for filing of briefs on the merits and certain other documents by letter to the Clerk, rather than by formal motion, and rule 54 includes the District of Columbia Court of Appeals in the definition of the term "state court." Two conforming changes pertain to the standard for granting certiorari. New rule 17 , replacing the familiar old rule I9, omits as one of the bases for certiorari that the decision of a federal court of appeals resolves "an important state or territorial question in a way in conflict with applicable state or territorial law." Doubtless this reflects the Court's general distaste for diversity jurisdiction. On the other hand, the new rule recognizes as a basis for certiorari a conflict on a question of federal law between a state court of last resort and a federal appellate court, or among state courts of last resort.

The new rules also have taken account of changing times by significantly increasing the various fees charged by the Court. Rule 45 now doubles the cost for docketing a case to $\$ 200$, to be increased to $\$ 300$ when argument is permitted. The fee for admission to the Bar has been quadrupled to $\$$ roo (rule $45(\mathrm{e})) .{ }^{25}$ And, whether as a revenue-raising measure or

${ }^{24}$ Rule 33.5(a) provides that all "documents" exceeding five pages shall be preceded by a table of contents, unless they contain only one item. Similarly, rule $33.5(\mathrm{~b})$ requires documents exceeding three pages to contain a table of authorities. Although stay applications and other motions are clearly to be considered documents under rule 33, see rule 33.6, the Clerk's office has taken the position that stay applications will be accepted whether or not preceded by tables of contents or tables of authorities. See Application for a Stay, Moore v. Brown, No. A-I95 (U.S., filed Aug. 28, 1980).

${ }^{25}$ Lest anyone suspect that this $\$ 75$ difference is considered trivial by today's reputedly overpaid attorney, it is reported that during May and June the resources of the Clerk's office were severely strained by a flood of 4,000 applications from attorneys eager to gain admission at the $\$ 25$ bargain rate. Telephone Conversation, stupra note 9.

It should be noted that admission to practice before the Court is more important under the new rules than under the old. As noted earlier, only a member of the Court's Bar may take advantage of the mail-in procedure for filing documents. See p. 3 17 supra. In addition, while old rule 47.2 provided that applications made before a case has been docketed (e.g., motions for extension of time to file petitions for certiorari) "must be signed . . . by the party or by counsel but . . . such counsel need not be a member of the bar of this court," new rule 39.2 specifies that such 
as a probably futile attempt at deterrence, petitions for rehearing now must be accompanied by a filing fee of $\$ 50$.

One other change merits discussion, not because of how much it accomplishes, but how little. Rule 30.7 , dealing with the filing of joint appendices in cases in which plenary review has been granted, now contains a provision permitting the filing of the appendix used in the court below "if it conforms to the requirements of this Rule." The joint appendix, which must be filed in virtually every case argued on the merits, generally involves hundreds of pages of custom printing at a cost of thousands of dollars. The prospect of simply filing the appendix used below therefore seemed like an eminently reasonable idea, but this could not be done under the old rules because of differing requirements as to document size. ${ }^{26}$ The new rule offered the hope that the Court would now accept the oversize appendices typically used in the lower courts. Yet this hope was dashed in one stroke by the Clerk's office, which informed us that rule 30's reference to rule 33 , which specifies document dimensions, would be interpreted as incorporating those dimensional constraints into "this Rule" - rendering the oversized court of appeals appendices still unacceptable for Supreme Court use. ${ }^{27}$

No book review would be complete without a few stylistic comments. Almost every one of the rules has been rewritten somewhat, even where no substantive changes have been made. For example, rules $\mathrm{I}_{5} \mathrm{I}(\mathrm{g})$ and $2 \mathrm{I} . \mathrm{I}(\mathrm{g})$, dealing with jurisdictional statements and petitions for certiorari, now italicize the word "concise" when exhorting attorneys to be brief in their statement of the case. (Curiously, the parallel "concise" in rule $34 . \mathrm{I}(\mathrm{g})$, dealing with the statement of the case in briefs on the merits, was left unitalicized.) A rather cryptic change is reflected in the new rule 17 . Old rule $x 9$ provided that "[a] review on writ of certiorari is not a matter or right, but of sound judicial discretion" (emphasis added). The new rule is identical, except that the italicized word is conspicu-

motions must be signed by counsel of record. Although "counsel of record" is a nebulous concept, see note 6 supra, it would seem at least to require membership in the Bar of the Court. Finally, the old rules were silent as to whether a petition for an extraordinary writ could be filed by a lawyer not a member. Rule 27. . now specifies that an appearance of counsel form must be filed at the time of filing a petition for an extraordinary writ, and this form may be filed only by a member of the Court's Bar.

${ }^{26}$ Court of appeals appendices are normally reproduced by photocopying the relevant documents in a volume $81 / 2 \times$ Ir inches in size, see FED. R. APP. P. 32(a), while all documents filed in the Supreme Court must be $61 / 8 \times 7^{1 / 1}$ inches.

27 Telephone Conversation, supra note 9. 
ously omitted. Although the uncharitable reader might infer from this that henceforth the Court will exercise arbitrary and capricious - rather than sound - discretion in ruling on these petitions, we prefer to think that the rewording serves merely to remedy a redundancy.

In a few instances, however, the Court appears to have been somewhat carried away with clarifying its intentions. Rule 38 , dealing with oral argument, is a good example. The Court has not only added the exhortation that "Counsel should assume that all Members of the Court have read the briefs in advance of argument," but immediately following has thought it necessary to italicize the admonition that "[ $t]$ he Court looks with disfavor on any oral argument that is read from a prepared text" (rule 38.I). And, in what can only be characterized as an overabundance of caution, rule 38.3 now informs counsel that they are "not required to use all the allotted time" for oral argument. Finally, the new rules have taken to capitalizing the terms Court, Justice, Clerk, Bar, etc. While this no doubt reflects the proper respect for these institutions, there is something to be said for the understated elegance of the old rules, where the terms were in lower case. ${ }^{28}$

Altogether it must be concluded that the Court has done an admirable job of revising its rules. Generally, the rules clarify and simplify the practice before the Court. We are happy to say that the changes in wording are also, for the most part, salutary; as far as rules can be, the new rules are readable and easy to follow. Although we have pointed out some potential problems, only time and experience will show whether the new procedures are workable. The Court has shown a willingness to reconsider rule changes that have proven unworkable or ineffective. One hopes that it will continue to do so should problems develop with these most recent reforms.

\footnotetext{
${ }^{28}$ But see A UNIFORM SySTEM OF Citation 25-28 (12th ed. 1976) (mandating capitalization of "Court," "Term," and "Justice," inter alia).
} 